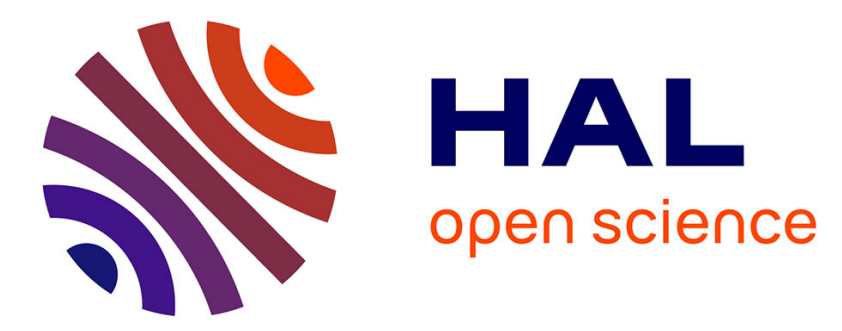

\title{
Synthesis of picolinohydrazides and their evaluation as ligands in the zinc-catalyzed hydrosilylation of ketones
}

\author{
V. Surzhko, T. Roisnel, B. Le Grel, P. Le Grel, C. Lalli, G. Argouarch
}

\section{To cite this version:}

V. Surzhko, T. Roisnel, B. Le Grel, P. Le Grel, C. Lalli, et al.. Synthesis of picolinohydrazides and their evaluation as ligands in the zinc-catalyzed hydrosilylation of ketones. Tetrahedron Letters, 2017, 58 (13), pp.1343-1347. 10.1016/j.tetlet.2017.02.062 . hal-01515172

HAL Id: hal-01515172

https://hal-univ-rennes1.archives-ouvertes.fr/hal-01515172

Submitted on 4 Jul 2017

HAL is a multi-disciplinary open access archive for the deposit and dissemination of scientific research documents, whether they are published or not. The documents may come from teaching and research institutions in France or abroad, or from public or private research centers.
L'archive ouverte pluridisciplinaire HAL, est destinée au dépôt et à la diffusion de documents scientifiques de niveau recherche, publiés ou non, émanant des établissements d'enseignement et de recherche français ou étrangers, des laboratoires publics ou privés. 


\section{Synthesis of picolinohydrazides and their evaluation as ligands}

\section{in the zinc-catalyzed hydrosilylation of ketones}

Vita Surzhko a, Thierry Roisnel ${ }^{\mathrm{b}}$, Barbara Le Grel ${ }^{\mathrm{a}}$, Philippe Le Grel ${ }^{\mathrm{a}, *}$, Claudia Lalli ${ }^{a}$, Gilles

Argouarch $^{\mathrm{a}, *}$

Université de Rennes 1, UMR CNRS 6226, Institut des Sciences Chimiques de Rennes, Equipe CORINT, UFR des Sciences Biologiques et Pharmaceutiques, 2 Avenue du Professeur Léon Bernard, 35043 Rennes Cedex, France

E-mail addresses: gilles.argouarch@univ-rennes1.fr; philippe.legrel@univ-rennes1.fr.

Université de Rennes 1, UMR CNRS 6226, Institut des Sciences Chimiques de Rennes, Centre de Diffractométrie X, 263 Avenue du Général Leclerc, 35042 Rennes Cedex, France 


\title{
Keywords
}

Hydrosilylation, Zinc, Hydrazides, Ketones

\begin{abstract}
A set of picolinohydrazides was prepared by reaction between hydrazines and either 2-picolinic acid or ethyl pyridine-2-carboxylate, and characterized. These molecules were evaluated as ligands in the zinc-catalyzed hydrosilylation of ketones. Thus, several aromatic and aliphatic ketones were successfully reduced by diethoxymethylsilane as the hydride source in the presence of a catalytic system made of diethylzinc combined in situ to the picolinohydrazides described herein.
\end{abstract}

\section{Introduction}

In the past years the importance of zinc(II) complexes in homogeneous catalysis has increased to fulfil the need for more economical and less toxic processes in modern organic chemistry. ${ }^{1}$ Among recent advances in this field, zinc-based catalysts have been successfully applied in the hydrosilylation of aldehydes and ketones, ${ }^{2-4}$ but also of more challenging substrates such as imines, ${ }^{5}$ amides, ${ }^{6}$ esters, ${ }^{7}$ or even $\mathrm{CO}_{2}{ }^{8}$ In the hydrosilylation of aldehydes and ketones, consisting of the addition of a hydrosilane to the carbonyl group followed by hydrolysis of the silyl ether intermediate to release the corresponding alcohol, the reduction reaction operates under very mild conditions and is therefore an attractive alternative to catalytic hydrogenation or hydrogen transfer. Thus a growing number of catalytic systems based on zinc that display excellent activities for this reaction have been described to date, ${ }^{2,3}$ and this also include chiral systems that allow for high enantioselectivities in asymmetric hydrosilylation of prochiral ketones. ${ }^{4}$ Apart from some limited examples of well-defined zinc complexes (or clusters) which have been reported on as active pre-catalysts in this area, ${ }^{3}$ most of these catalytic systems are 


\section{ACCEPTED MANUSCRIPT}

typically formed in situ by combining a cheap and readily available zinc precursor, namely diethylzinc or zinc(II) acetate, with various ligands. In a seminal contribution by Mimoun et al., ${ }^{4 a}$ the activation of diethylzinc by diamine-type ligands was found particularly effective for the hydrosilylation reduction, and this led to the prominent use of numerous nitrogen-chelating ligands, whether or not chiral, that have contributed later on to the development of this reaction.

Hydrazides constitute an important class of molecules because of the high reactivity of these $N$ acylhydrazine derivatives which makes them valuable building blocks for the synthesis of many pharmaceuticals and materials. ${ }^{9}$ On the other hand, contributions to catalysis in which ligands are functionalized by a $\mathrm{CO}-\mathrm{N}-\mathrm{N}$ hydrazide moiety remain scarce, ${ }^{10}$ and the appealing coordination properties of this fragment, possessing the unusual nitrogen-nitrogen $\sigma$-bond, to transition metals stay largely under-examined. Herein, we report on the preparation of several picolinohydrazides differently substituted on the $N^{\alpha}$ - and $N^{\beta}$-positions, some of which are new and were fully characterized. Our results on their ability to serve as efficient ligands in the zinc-catalyzed hydrosilylation of ketones are also presented.

\section{Results and discussion}

One general approach to the synthesis of acylated hydrazines is condensation of a carboxylic acid activated by a peptide coupling reagent with a hydrazine. According to this method, the reaction between 2-picolinic acid (1) and various hydrazines afforded a first set of picolinohydrazide ligands L1-L6 (Scheme 1). In the case of hydrazine hydrochlorides $\mathbf{2 . H C l}{ }^{11}$ and $\mathbf{3 . H C l}{ }^{12}$ the TBTU promoted acylation in the presence of $\mathbf{1}$ was preferred because the excess of $\mathrm{K}_{2} \mathrm{CO}_{3}$ required for this reaction can release in situ the corresponding free hydrazines. After reaction and purification by flash chromatography, pure compounds $\mathbf{L 1}$ and $\mathbf{L 2}$ were isolated in high yields. With hydrazines 4-7, the coupling reactions were readily achieved by using CDI in $\mathrm{CH}_{2} \mathrm{Cl}_{2}$ and gave products $\mathbf{L 3}-\mathbf{L 6}$ with satisfying yields after purification by trituration or recrystallization. Compounds $\mathbf{L} \mathbf{4}^{13}$ and $\mathbf{L 5}^{13,14}$ have 


\section{ACCEPTED MANUSCRIPT}

been already prepared under different reaction conditions, and the spectroscopic data that we obtained were comparable with those of the literature.

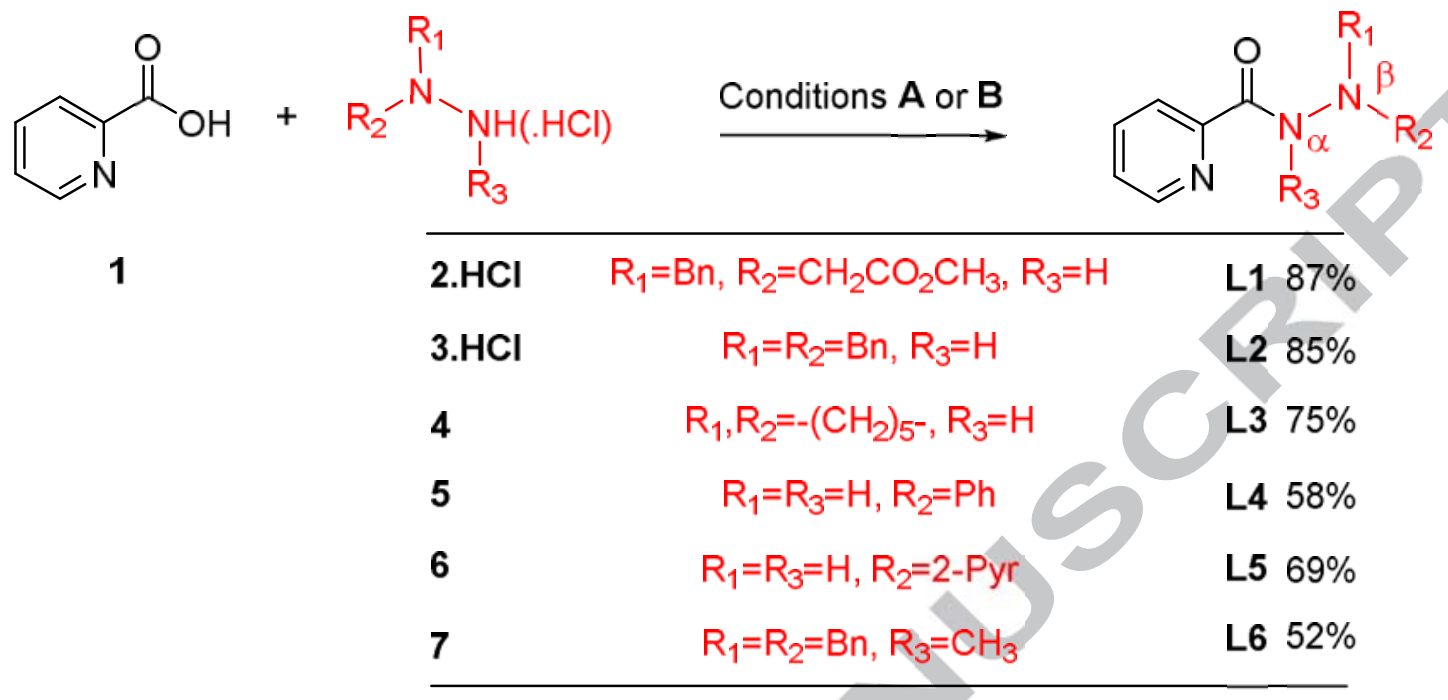

Scheme 1. Synthesis of picolinohydrazides L1-L6 using peptide coupling reagents. Conditions A for L1 and L2: 1 (1 equiv.), hydrazine hydrochloride (1 equiv.), TBTU (1 equiv.), $\mathrm{K}_{2} \mathrm{CO}_{3}$ (4 equiv.), DMF, THF, rt, 12 h. Conditions B for L3-L6: 1 (1.2 equiv.), hydrazine (1 equiv.), CDI (1.2 equiv.), $\mathrm{CH}_{2} \mathrm{Cl}_{2}$, $\mathrm{rt}, 12 \mathrm{~h}$.

Another standard procedure to prepare carboxylic acid hydrazides is hydrazinolysis of esters in alcoholic solutions. Using this method, the reaction of ethyl pyridine-2-carboxylate $(\mathbf{8})$ with an excess of hydrazine (9) or methylhydrazine (10) in ethanol gave hydrazides $\mathbf{L 7}$ and $\mathbf{L 8}$ (Scheme 2). The new compound $\mathbf{L 8}$ was isolated in pure form as a white solid with $85 \%$ yield, and was readily identified by the usual analytical techniques. Noteworthy is the regioselectivity of this condensation since no acylation reaction took place on the $\mathrm{NH}_{2}$ position of methylhydrazine presumably because of its lower nucleophilicity if compared to the one at the NHMe terminus. On the other hand, picolinohydrazide $\mathbf{L 7}$ is a commercially available building block extensively used in various fields of synthesis, ranging from pharmaceuticals to photoswitches or sensors. ${ }^{15}$ In the presence of benzaldehyde, this reactive molecule was easily converted into the intermediate hydrazone $\mathbf{1 1}$ that underwent reduction with $\mathrm{NaBH}_{3} \mathrm{CN}$ to 
give ligand $\mathbf{L 9}$ which was fully characterized. ${ }^{16}$ In addition, the crystal structure of $\mathbf{L 9}$ was unequivocally determined by X-ray diffraction analyses. ${ }^{17}$<smiles>O=C([O-])c1ccccn1</smiles>

8<smiles>CCOCCOC=O</smiles>
$90 \%$<smiles>c1ccccc1</smiles><smiles>[R]NN</smiles>

$\mathrm{R}=\mathrm{H} \quad 9$

$\mathrm{R}=\mathrm{Me} 10$<smiles>O=C(N/N=C/c1ccccc1)c1ccccn1</smiles><smiles>CO</smiles>

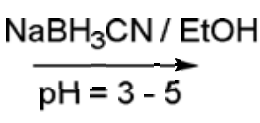

$76 \%$<smiles>[R]N(N)C(=O)c1ccccn1</smiles>

$\mathrm{R}=\mathrm{H} \quad \mathrm{L7}(57 \%)$

$\mathrm{R}=\mathrm{Me} \mathbf{L} \mathbf{8}(85 \%)$<smiles>O=C(NNCc1ccccc1)c1ccccn1</smiles>

L9

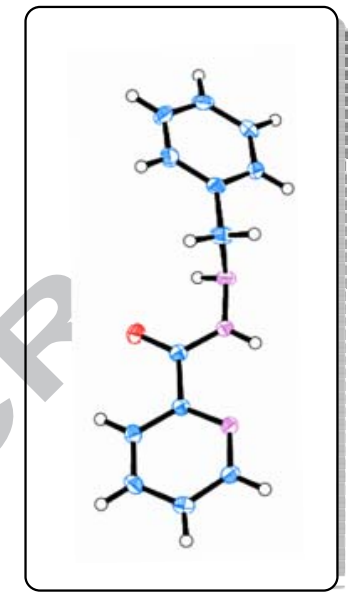

Scheme 2. Synthesis of picolinohydrazides L7-L9 and molecular diagram of ligand L9 at the 50\% probability level.

After preparation and characterization of picolinohydrazides $\mathbf{L 1 - L 9}$, and in connection with some of our earlier work, ${ }^{18}$ we were interested in the catalytic performance of this ligand class in the zinccatalyzed hydrosilylation of carbonyl compounds. Typical reaction conditions for our initial screening on acetophenone (12a) as the model substrate were chosen with the relatively cheap diethoxymethylsilane as the reducing agent, toluene as the solvent, and $5 \mathrm{~mol} \%$ of an in situ generated zinc catalyst composed of diethylzinc and the ligand in a ratio of 1:1 (Scheme 3). After $16 \mathrm{~h}$ of reaction at room temperature, the generated silyl ether was hydrolyzed under basic conditions to release the corresponding 1-phenylethanol (13a). Overall, the above results have shown that the degree of substitution of the ligand had a major influence on the outcome of the reaction. Thus, when hydrazides L1-L3 bearing two substituents at the $N^{\beta}$-position were first tested, near-quantitative conversions were obtained. Despite their very different functionalization, the $N^{\beta}$-unsubstituted ligands $\mathbf{L 7}$ and $\mathbf{L 8}$ also gave a complete conversion of acetophenone. On the contrary, for hydrazides L4 and L9 possessing only one substituent at the $N^{\beta}$-position, significantly lower conversions were observed (88\% and $74 \%$, 


\section{ACCEPTED MANUSCRIPT}

respectively). A reduced conversion of $93 \%$ was found with the fully substituted hydrazide L6, probably for steric reasons. Finally, in the case of $\mathbf{L 5}$ incorporating two pyridine moieties, almost no reduction occurred presumably because of its specific ligation to the zinc precluding any access of the reactants to the metal center. In those reactions, when complete conversions were reached, 13a was purified by column chromatography and the average isolated yields were $82 \%$. This rather low value may be attributed to some loss during the treatment, as no other product derived from 12a could be detected by NMR after hydrolysis (see Supporting Information for an example).

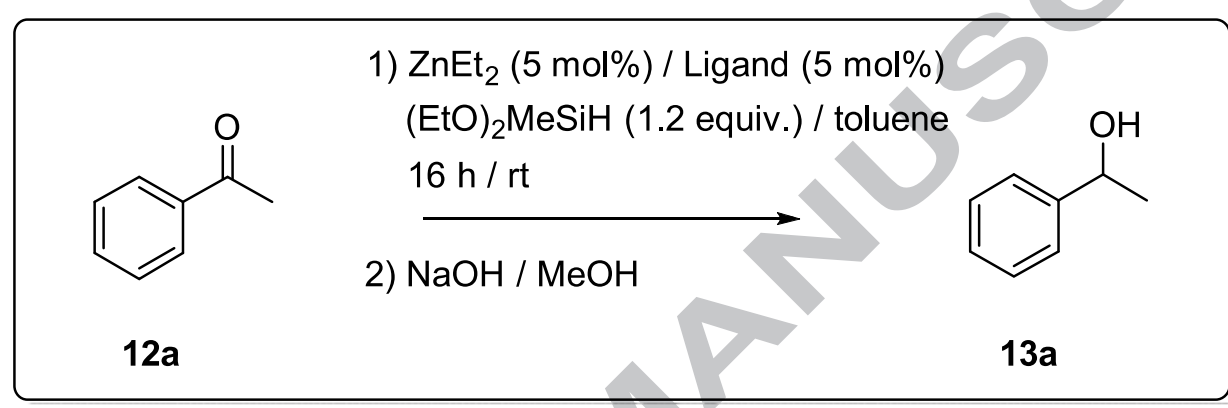<smiles>CC(=O)CN(Cc1ccccc1)NC(=O)c1ccccn1</smiles>

L1 $>99 \%(83 \%)$<smiles>O=C(NNc1ccccc1)c1ccccn1</smiles>

L4 $88 \%$<smiles>NNC(=O)c1ccccn1</smiles>

L7 $>99 \%(90 \%)$<smiles>O=C(NN(Cc1ccccc1)Cc1ccccc1)c1ccccn1</smiles>

L2 $>99 \%(87 \%)$<smiles>O=C(NNc1ccccn1)c1ccccn1</smiles>

L5 $<1 \%$<smiles>CN(N)C(=O)c1ccccn1</smiles>

L8 $>99 \%(78 \%)$<smiles>O=C(NN1CCCCC1)c1ccccn1</smiles>

L3 $>99 \%(71 \%)$<smiles>CN(C(=O)c1ccccn1)N(Cc1ccccc1)Cc1ccccc1</smiles>

L6 $93 \%$<smiles>O=C(NNCc1ccccc1)c1ccccn1</smiles>

L9 $74 \%$<smiles>O=C(NCc1ccccc1)c1ccccn1</smiles>

$1463 \%$<smiles>COC(=O)CN(Cc1ccccc1)NC(=O)c1ccccc1</smiles>

$1578 \%$

Scheme 3. Evaluation of the picolinohydrazides in the zinc-catalyzed hydrosilylation of acetophenone.

Conversions determined by ${ }^{1} \mathrm{H}$ NMR spectroscopy after basic hydrolysis are provided for each ligand, and isolated yields are given in parentheses. 
In order to further extend this preliminary study, other hydrosilylation trials were made on the model substrate. In particular, a very low conversion was observed in the absence of ligand, which was consistent with previous observations. ${ }^{4 a}$ Some attempts to decrease the catalyst loading were also conducted with $\mathbf{L} 2$ and proved to be detrimental to the acetophenone consumption since the use of 2.5 mol\% and $1 \mathrm{~mol} \%$ catalyst led to $92 \%$ and $74 \%$ conversion, respectively. When $N$-benzylpicolinamide $(\mathbf{1 4})^{19}$ or the benzohydrazide-type compound $\mathbf{1 5}$ were applied to the reaction, rather low conversions were obtained, highlighting the beneficial role of suitably substituted picolinohydrazide functionalities to the reaction. At last, one may also wonder if acetophenone could condense onto ligand $\mathbf{L 7}$ (or $\mathbf{L 8}$ ) in the course of the reaction to form the corresponding hydrazone that could act as the active ligand. Actually, control experiments between stoichiometric amounts of hydrazide L7 and this ketone in toluene solutions, in the presence or not of $\mathrm{ZnEt}_{2}$, were run and monitored by ${ }^{1} \mathrm{H}$ NMR spectroscopy, but no trace of condensation product could be detected in the reaction medium.

A series of representative acetophenone derivatives were next hydrosilylated with the combination of diethylzinc and selected picolinohydrazides $\mathbf{L 1}, \mathbf{L 2}$, and $\mathbf{L 7}$, to study the scope and limitations of the reaction (Table 1). Regardless the electron-withdrawing group present within the para-substituted ketones 12b-12f, high conversions as well as good yields were obtained with either L1 or L2 (entries 1-5). For 4'-methylacetophenone (12g), the conversion was only of $79 \%$ with $\mathbf{L 2}$ (entry 6), but could be satisfyingly raised over 99\% using L7 (entry 7). With stronger electron-donating substituents, decent conversions were attained for $\mathbf{1 2 h}(91 \%$, entry 8$)$ and $\mathbf{1 2} \mathbf{i}(81 \%$, entry 9$)$. Complete reduction was also observed with ketones $\mathbf{1 2} \mathbf{j}-\mathbf{1 2 l}$ (entries 10-13), although the latter was an ortho-substituted acetophenone.

\section{Table 1}

Scope of zinc-catalyzed hydrosilylation of acetophenone derivatives with $\mathbf{L 1}, \mathbf{L 2}$, and $\mathbf{L} \mathbf{7}^{\mathrm{a}}$ 
<smiles>[R]c1ccc(C(C)=O)cc1</smiles>

$12 b-I$
1) $\mathrm{ZnEt}_{2}$ (5 mol\%) / Ligand (5 mol\%) $(\mathrm{EtO})_{2} \mathrm{MeSiH}$ (1.2 equiv.) / toluene $16 \mathrm{~h} / \mathrm{rt}$

2) $\mathrm{NaOH} / \mathrm{MeOH}$<smiles>[R]c1ccc(C(C)O)cc1</smiles>

13b-I

\begin{tabular}{|c|c|c|c|c|c|}
\hline Entry & Substrate & $\mathrm{R}$ & Ligand & Conv. $^{\mathrm{b}}(\%)$ & ield $^{\mathrm{c}}(\%)$ \\
\hline 1 & 12b & $4-\mathrm{Cl}$ & L1 & $>99$ & 89 \\
\hline 2 & $12 \mathrm{c}$ & $4-\mathrm{F}$ & L2 & & 84 \\
\hline 3 & 12d & $4-\mathrm{CN}$ & $\mathbf{L 2}$ & & 65 \\
\hline 4 & $12 e$ & $4-\mathrm{NO}_{2}$ & $\mathbf{L 2}$ & 97 & 89 \\
\hline 5 & $12 \mathrm{f}$ & $4-\mathrm{Br}$ & L1 & $>99$ & 85 \\
\hline 6 & $12 \mathrm{~g}$ & $4-\mathrm{CH}_{3}$ & L2 & 79 & - \\
\hline 7 & $12 \mathrm{~g}$ & $4-\mathrm{CH}_{3}$ & L7 & $>99$ & 90 \\
\hline 8 & $12 \mathrm{~h}$ & $4-\mathrm{OCH}_{3}$ & $\mathbf{L 2}$ & 91 & - \\
\hline 9 & $12 \mathbf{i}$ & & L7 & 81 & - \\
\hline 10 & $12 j$ & 4-Ph & L1 & $>99$ & 91 \\
\hline 11 & $12 j$ & 4-Ph & L7 & $>99$ & 78 \\
\hline 12 & & $3-\mathrm{OCH}_{3}$ & L7 & $>99$ & 91 \\
\hline 13 & 121 & $2-\mathrm{Cl}$ & L7 & $>99$ & 85 \\
\hline
\end{tabular}

${ }^{\mathrm{a}}$ Typical conditions: substrate $(1 \mathrm{mmol})$, diethoxymethylsilane $(1.2 \mathrm{mmol})$, diethylzinc $(0.05 \mathrm{mmol})$, ligand $(0.05 \mathrm{mmol})$, toluene $(2 \mathrm{~mL}), 16 \mathrm{~h}, \mathrm{rt}$.

${ }^{\mathrm{b}}$ Conversion determined by ${ }^{1} \mathrm{H}$ NMR spectroscopy after basic hydrolysis.

${ }^{\mathrm{c}}$ Isolated yield after purification by column chromatography.

Encouraged by the good results obtained with acetophenone and its congeners, we decided to try in turn more challenging carbonyl substrates (Table 2). First, the ability of the catalytic system to reduce 


\section{ACCEPTED MANUSCRIPT}

bulky ketones was probed by using propiophenone (16a), isobutyrophenone (16b), and $\alpha$-tetralone

(16c). These compounds underwent complete transformation provided that the right ligand was employed. For instance, L1 was efficient on 16a (entry 1) but found its limit with 16c (entry 4), whereas $\mathbf{L 2}$ gave a clean reduction of $\mathbf{1 6 c}$ (entry 5) but a partial conversion of $\mathbf{1 6 \mathbf { b }}$ (entry 2). Nevertheless, when the hydrosilylation of $\mathbf{1 6 b}$ was carried out with $\mathbf{L 7}$, alcohol $\mathbf{1 7 b}$ was formed quantitatively (entry 3). No problem was encountered in the reduction of the activated ketone 16d with either $\mathbf{L} \mathbf{1}$ or $\mathbf{L} \mathbf{2}$ (entries 7 and 8).

\section{Table 2}

Scope of zinc-catalyzed hydrosilylation of various carbonyl compounds with $\mathbf{L 1}, \mathbf{L} 2$, and $\mathbf{L} \mathbf{7}^{\mathrm{a}}$<smiles>[R]C([R])=O</smiles>

$16 a-j$

1) $\mathrm{ZnEt}_{2}$ (5 mol\%) / Ligand (5 mol\%) $(\mathrm{EtO})_{2} \mathrm{MeSiH}$ (1.2 equiv.)/ toluene

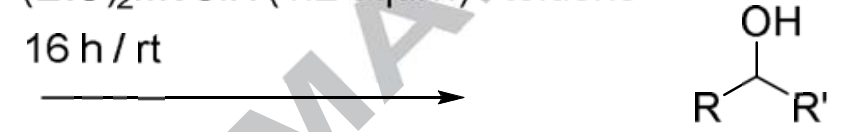

2) $\mathrm{NaOH} / \mathrm{MeOH}$

17a-j

\begin{tabular}{|c|c|c|c|c|}
\hline Entry & & Ligand & Conv. $^{b}(\%)$ & Yield $^{c}(\%)$ \\
\hline \multirow[t]{3}{*}{1} & $16 a$ & L1 & $>99$ & 75 \\
\hline & $16 b$ & L2 & 82 & - \\
\hline & & L7 & $>99$ & 93 \\
\hline 4 & & L1 & 89 & - \\
\hline 5 & $16 c$ & $\mathbf{L 2}$ & $>99$ & 78 \\
\hline 6 & & L7 & $>99$ & 92 \\
\hline
\end{tabular}




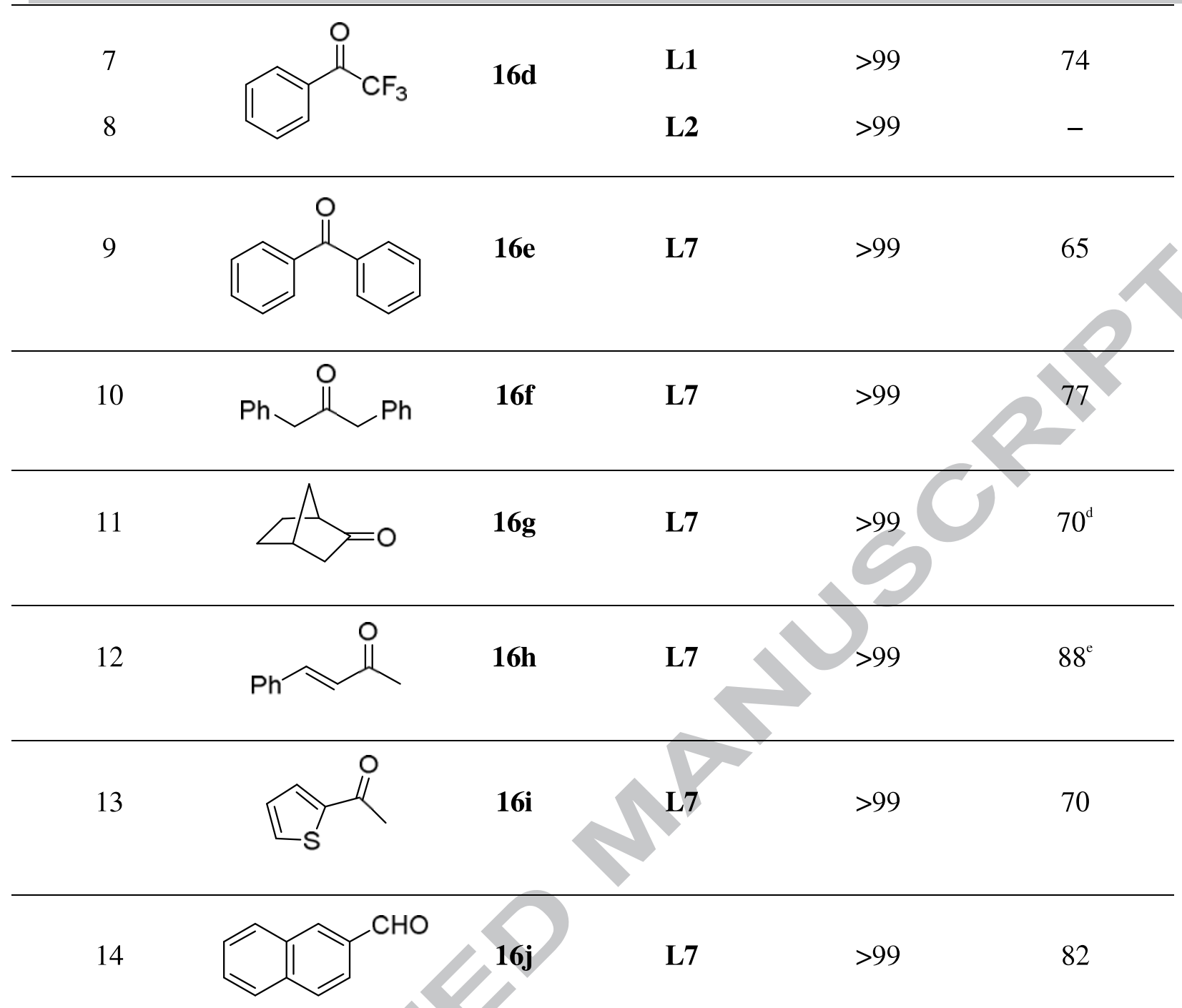

${ }^{a}$ Typical conditions: substrate $(1 \mathrm{mmol})$, diethoxymethylsilane $(1.2 \mathrm{mmol})$, diethylzinc $(0.05 \mathrm{mmol})$, ligand $(0.05 \mathrm{mmol})$, toluene $(2 \mathrm{~mL}), 16 \mathrm{~h}, \mathrm{rt}$.

${ }^{\mathrm{b}}$ Conversion determined by ${ }^{1} \mathrm{H}$ NMR spectroscopy after basic hydrolysis.

${ }^{\mathrm{c}}$ Isolated yield after purification by column chromatography.

${ }^{\mathrm{d}}$ Endolexo $=85 / 15$.

${ }^{\mathrm{e}}$ Mixture of products: 4-phenylbut-3-en-2-ol (80\%) and 4-phenylbutan-2-ol (20\%).

On the basis of the foregoing and given its availability, ligand $\mathbf{L 7}$ was retained for the following assays. Excellent conversions were obtained for benzophenone (16e), dibenzyl ketone (16f), 2norbornanone (16g), and 2-acetylthiophene (16i) (entries 9-11 and 13). The $\alpha, \beta$-unsaturated ketone 16h 


\section{ACCEPTED MANUSCRIPT}

was also investigated (entry 12), and in this case the expected allylic alcohol $\mathbf{1 7 h}$ together with 4 phenylbutan-2-ol were present in the final product in a ratio 4:1. As expected with the more reactive aldehydes, when the reaction was carried out on 2-naphthaldehyde (16j) as a representative example, a complete conversion was reached (entry 14).

\section{Conclusion}

In the present study, we have demonstrated the high catalytic performance of diethylzinc combined with picolinohydrazides in the hydrosilylation of carbonyl compounds under mild conditions. This novel in situ system allowed the efficient reduction of a wide variety of (hetero)aromatic and aliphatic ketones with broad functional group tolerance, and when some steric limitations arose they could be circumvented. Aldehydes and enone-containing substrates were also readily transformed, although for these latter some loss in selectivity was observed. In short, picolinohydrazides constitute a class of easily accessible molecules able to serve as efficient ligands for zinc-catalyzed hydrosilylation. It would be now worth devoting future work in the direction of enantioselective hydrosilylation of prochiral ketones based on zinc catalysts of chiral hydrazides.

\section{Acknowledgments}

We thank Université de Rennes 1 and CNRS for financial support, and FEDER funds for acquisition of single crystal equipment.

\section{Supplementary data}

Supplementary data associated with this article can be found, in the online version, at 


\section{References}

1. S. Enthaler, ACS Catal. 2013, 3, 150-158.

2. a) T. Ohkuma, S. Hashiguchi, R. Noyori, J. Org. Chem. 1994, 59, 217-221; b) H. Mimoun, J. Org. Chem. 1999, 64, 2582-2589; c) V. Bette, A. Mortreux, C. W. Lehmann, J.-F. Carpentier, Chem. Commun. 2003, 332-333; d) M. Kahnes, H. Görls, L. Gonzalez, M. Westerhausen, Organometallics 2010, 29, 3098-3108; e) N. A. Marinos, S. Enthaler, M. Driess, ChemCatChem 2010, 2, 846-853; f) S. Enthaler, K. Schröder, S. Inoue, B. Eckhardt, K. Junge, M. Beller, M. Driess, Eur. J. Org. Chem. 2010, 4893-4901; g) S. Enthaler, B. Eckhardt, S. Inoue, E. Irran, M. Driess, Chem. Asian J. 2010, 5, 2027-2035; h) H. Ozasa, K. Kondo, T. Aoyama, Chem. Pharm. Bull. 2010, 58, 989-990.

3. a) C. Boone, I. Korobkov, G. I. Nikonov, ACS Catal. 2013, 3, 2336-2340; b) A. Rit, A. Zanardi, T. P. Spaniol, L. Maron, J. Okuda, Angew. Chem. Int. Ed. 2014, 53, 13273-13277; c) P. A. Lummis, M. R. Momeni, M. W. Lui, R. McDonald, M. J. Ferguson, M. Miskolzie, A. Brown, E. Rivard, Angew. Chem. Int. Ed. 2014, 53, 9347-9351; d) Z. Mou, H. Xie, M. Wang, N. Liu, C. Yao, L. Li, J. Liu, S. Li, D. Cui, Organometallics 2015, 34, 3944-3949; e) W. Sattler, S. Ruccolo, M. Rostami Chaijan, T. Nasr Allah, G. Parkin, Organometallics 2015, 34, 4717-4731.

4. a) H. Mimoun, J.-Y. de Saint Laumer, L. Giannini, R. Scopelliti, C. Floriani, J. Am. Chem. Soc. 1999, 121, 6158-6166; b) V. M. Mastranzo, L. Quintero, C. Anaya de Parrodi, E. Juaristi, P. J. Walsh, Tetrahedron 2004, 60, 1781-1789; c) V. Bette, A. Mortreux, D. Savoia, J.-F. Carpentier, Tetrahedron 2004, 60, 2837-2843; d) V. Bette, A. Mortreux, F. Ferioli, G. Martelli, D. Savoia, J.-F. Carpentier, Eur. J. Org. Chem. 2004, 3040-3045; e) V. Bette, A. Mortreux, D. Savoia, J.-F. Carpentier, Adv. Synth. Catal. 2005, 347, 289-302; f) S. Gérard, Y. Pressel, O. Riant, Tetrahedron: Asymmetry 2005, 16, 1889-1891; g) H. Ushio, K. Mikami, Tetrahedron Lett. 2005, 


\section{ACCEPTED MANUSCRIPI}

46, 2903-2906; h) M. Bandini, M. Melucci, F. Piccinelli, R. Sinisi, S. Tommasi, A. UmaniRonchi, Chem. Commun. 2007, 4519-4521; i) J. Gajewy, M. Kwit, J. Gawronski, Adv. Synth. Catal. 2009, 351, 1055-1063; j) E. Santacruz, G. Huelgas, S. K. Angulo, V. M. Mastranzo, S. Hernández-Ortega, J. A. Aviña, E. Juaristi, C. Anaya de Parrodi, P. J. Walsh, Tetrahedron: Asymmetry 2009, 20, 2788-2794; k) K. Junge, K. Möller, B. Wendt, S. Das, D. Gördes, K. Thurow, M. Beller, Chem. Asian J. 2012, 7, 314-320; 1) S. Liu, J. Peng, H. Yang, Y. Bai, J. Li, G. Lai, Tetrahedron 2012, 68, 1371-1375; m) T. Zaman, R. Frauenlob, R. McCarthy, C. M. Walsh, E. Bergin, J. Organomet. Chem. 2012, 716, 159-166; n) S. Pang, J. Peng, J. Li, Y. Bai, W. Xiao,

G. Lai, Chirality 2013, 25, 275-280; o) D. Lowicki, A. Bezlada, J. Mlynarski, Adv. Synth. Catal. 2014, 356, 591-595; p) E. Le Roux, A. De Mallmann, N. Merle, M. Taoufik, R. Anwander, Organometallics 2015, 34, 5146-5154; q) M. Szewczyk, F. Stanek, A. Bezlada, J. Mlynarski, Adv. Synth. Catal. 2015, 357, 3727-3731; r) J. Gajewy, J. Szymkowiak, M. Kwit, RSC Adv. 2016, 6, 53358-53369; s) M. Szewczyk, A. Bezlada, J. Mlynarski, ChemCatChem 2016, 8, 3575-3579.

5. a) B.-M. Park, S. Mun, J. Yun, Adv. Synth. Catal. 2006, 348, 1029-1032; b) B.-M. Park X. Feng, J. Yun, Bull. Korean Chem. Soc. 2011, 32, 2960-2964; c) J. Gajewy, J. Gawronski, M. Kwit, Org. Biomol. Chem. 2011, 9, 3863-3870; d) A. Bezlada, M. Szewczyk, J. Mlynarski, J. Org. Chem. 2016, 81, 336-342; e) A. Adamkiewicz, J. Mlynarski, Eur. J. Org. Chem. 2016, 10601065; f) S. Enthaler, Catal. Lett. 2011, 141, 55-61.

6. a) S. Das, D. Addis, K. Junge, M. Beller, Chem. Eur. J. 2011, 17, 12186-12192; b) O. O. Kovalenko, A. Volkov, H. Adolfsson, Org. Lett. 2015, 17, 446-449; c) G. Ding, B. Lu, Y. Li, J. Wan, Z. Zhang, X. Xie, Adv. Synth. Catal. 2015, 357, 1013-1021.

7. O. O. Kovalenko, H. Adolfsson, Chem. Eur. J. 2015, 21, 2785-2788.

8. W. Sattler, G. Parkin, J. Am. Chem. Soc. 2012, 134, 17462-17465.

9. E. Licandro, D. Perdicchia, Eur. J. Org. Chem. 2004, 665-675. 


\section{ACCEPTED MANUSCRIPT}

10. For some examples see: a) K. Ahlford, J. Ekström, A. B. Zaitsev, P. Ryberg, L. Eriksson, H. Adolfsson, Chem. Eur. J. 2009, 15, 11197-11209; b) J. Xie, X. Zhu, M. Huang, F. Meng, W. Chen, Y. Wan, Eur. J. Org. Chem. 2010, 3219-3223; c) C. Chuanling, W. Wenliang, Chin. J. Chem. 2011, 29, 196-198; d) E. Gould, T. Lebl, A. M. Z. Slawin, M. Reid, T. Davies, A. D. Smith, Org. Biomol. Chem. 2013, 11, 7877-7892; e) S. A. Timofeeva, M. A. Kinzhalov, E. A. Valishina, K. V. Luzyanin, V. P. Boyarshiy, T. M. Buslaeva, M. Haukka, V. Y. Kukushkin, J. Catal. 2015, 329, 449-456.

11. a) A. Cheguillaume, A. Salaün, S. Sinbandhit, M. Potel, P. Gall, M. Baudy-Floc'h, P. Le Grel, J. Org. Chem. 2001, 66, 4923-4929; b) A. Salaün, M. Potel, T. Roisnel, P. Gall, P. Le Grel, J. Org. Chem. 2005, 70, 6499-6502.

12. a) P. Le Grel, A. Salaün, C. Mocquet, B. Le Grel, T. Roisnel, M. Potel, J. Org. Chem. 2011, 76, 8756-8767; b) D. Prasad, V. N. Sinha, N. Prasad, Nat. Acad. Sci. Lett. 1985, 8, 115-118.

13. J. Garric, J.-M. Léger, A. Grelard, M. Ohkita, I. Huc, Tetrahedron Lett. 2003, 44, 1421-1424.

14. A. Moulin, J. Martinez, J.-A. Fehrentz, Tetrahedron Lett. 2006, 47, 7591-7594.

15. For some recent applications see: a) G. L. Backes, B. S. Jursic, D. M. Neumann, Bioorg. Med. Chem. 2015, 23, 3397-3407; b) D. Jan van Dijken, P. Kovaricek, S. P. Ihrig, S. Hecht, J. Am. Chem. Soc. 2015, 137, 14982-14991; c) G. Meng, Z. Chen, H. Tang, Y. Liu, L. Wei, Z. Wang, New J. Chem. 2015, 39, 9535-9542; d) C. Kar, S. Samanta, S. Goswami, A. Ramesh, G. Das, Dalton Trans. 2015, 44, 4123-4132; e) B. K. Datta, D. Thiyagarajan, S. Samanta, A. Ramesh, G. Das, Org. Biomol. Chem. 2014, 12, 4975-4982.

16. This compound was already present in the literature but full characterization was missing: T. S. Gardner, E. Wenis, J. Lee, J. Med. Pharm. Chem. 1960, 2, 133-145. 


\section{ACCEPTED MANUSCRIPT}

17. CCDC 1489601 contains the supplementary crystallographic data for this paper. These data can be obtained free of charge from the Cambridge Crystallographic Data Center.

18. T. Cordero Jung, G. Argouarch, P. van de Weghe, Catal. Commun. 2016, 78, 52-54.

19. A. M. Martinez, N. Rodriguez, R. G. Arrayas, J. C. Carretero, Chem. Commun. 2014, 50, 61056107. 

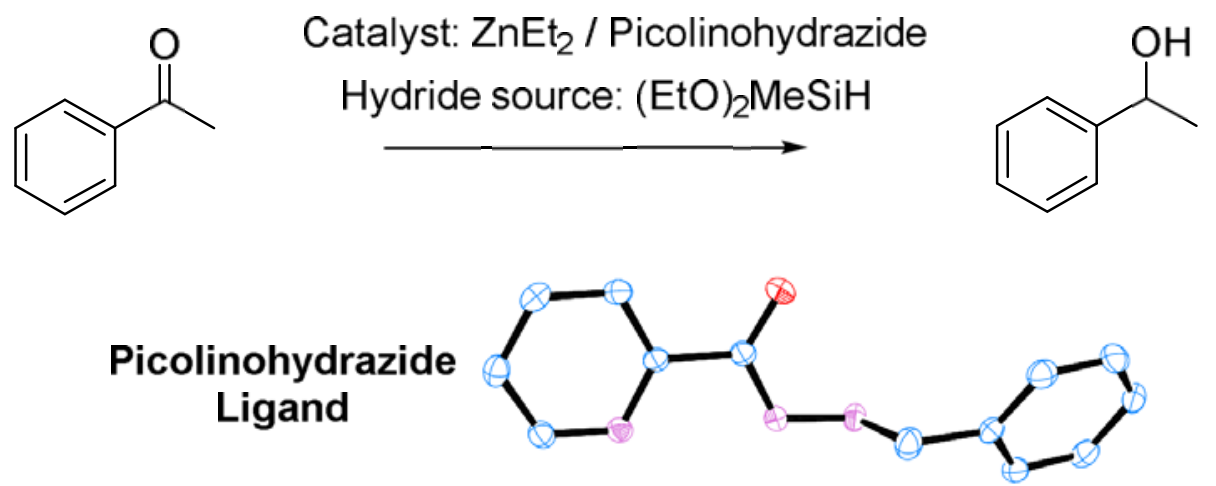
Novel picolinohydrazides were readily prepared and characterized.

They were combined with diethylzinc and used in hydrosilylation of ketones.

Over 20 ketones were reduced by diethoxymethylsilane and this catalytic system. 